Ранко В. Поповић ${ }^{1}$

Универзитет у Бањој Ауци

Фимолошки факултет

\title{
СРПСКА ПОЛИТИЧКА САТИРА У БОСНИ И ХЕРЦЕГОВИНИ С ПОЧЕТКА ДВАДЕСЕТОГ ВИЈЕКА
}

Апстракт: У нараштају писауа који су у Босни и Херцеговини рођени непосредно прије или у вријеме аустроугарске окупачије неколико них се истакло књижевним радовима који иду ужанр политичке сатире. Сви су они наставьали и довршавали дјело претходника на пољу борбе за црквено-школску аутономију и углавном били непосредно ангажовани као јавни дјелатничи за стицате културне аутономије, политичких начионалних права и спровођене аграрне реформе у корист домаћег сељака. Заједничка идеолошка платформа била им је бескомпромисна антиаустријска акција, која је често укључивала и жестоку критику домаћих политичких представника који су се залагали за компромис са окупатором. Најистакнутији међу таквим сатиричарима био је Петар Кочић, а дјело вриједно пажне у тој области створили су и Светозар Ћоровић и данас готово заборављени Саво Скарић Зембиљ.

Кључне ријечи: Петар Кочић, Светозар Ћоровић, Саво Скарић Зембиь, помитичка сатира, антиаустријска акиија.

Четири деценије аустроугарског присуства у Босни и Херцеговини преАстављају одвећ дуго и бројним друштвеним проблемима оптерећено вријеме да би се оно могло кратко и бар приближно јасно описати. Аолазак окупационих трупа на основу мандата који је Црно-жута монархија добима на Берлинском конгресу очекивано је морао донијети велика комешања, политичке смутње и национацне трауме. Аавањем Босне на изор ћесарокраву све је у отачаству nошло наопако, како би то рекао Кочићев Симеун Ђак. Муслимански народни 
елемент, национално неизграђен и додатно понижен у неуспјешном покушају краткотрајног оружаног отпора, био је најтеже погођен и потпуно дезоријентисан узмицањем поьуьане Отоманске империје. Ништа мање болне нису биме ни српске узалудне наде Аа ће двије дојучерашње турске покрајине бити присаједињене Србији и Црној Гори. Бројчано најмањи, једино су католици привидно мирно и с извјесним надама дочекали једновјерног окупатора; њих ће од тог тренутка, а нарочито интензивно након Првог хрватског католичког конгреса у Загребу 1900. године, чекати процес похрваћења у националном погледу. Окупационе вцасти користиле су сваку прилику да трајно и неповратно поцијепају јединствено народно ткиво. КаА се ствари сведу на основне узроке, могло би се рећи да је Монархија „једном руком чинила политички притисак да пригуши национални осјећај у народу, а другом је руком задржавала рјешење најважнијег питања земье, аграрног ими кметског питања“ (Blagojević 1936: 450).

У покушају потпуног изоловања домаћег живља од природних утицаја и Аотицаја који су постојали на релацији с Краљевином Србијом, босанска помитика Аустроугарске монархије бима је агресивно антисрпска, а као одговор на њу развица се доста брзо јака национацна акција која се кретала од стварања првих школа, читаоница, потпорних организација, друштава за народно просвјећивање, штампарија, Аистова и часописа, преко снажног покрета за вјерско-просвјетну аутономију па до формирања широког политичког фронта коме је иницијалне подстицаје даца српска академска омладина. Сви облици отпора били су драгоцјени, а и књижевност је међу њима имаха посебно и важно мјесто. Српска политичка сатира у Босни и Херцеговини јавња се тако у јеку антиаустријске политичке акције и показује све њене особености, а њени ствараоци су писци који су истовремено активни политички дјелатници и народни трибуни. Предњачи Петар Кочић, који је свог Јазавца пред судом као приповијетку већ поткрај новембра 1903, као студент у Бечу, читао пред чиановима академског друштва Зора. Након њега јавьа се у сарајевској Српској ријечи, августа 1906, Саво Скарић својим феьтоном Зембиљ, чије је објавьивање прекинуто ауторовом прераном смрћу 1909. Прво годиште мостарског Народа доноси 1907. у шест наставака најзначајнију сатиру Светозара Ћоровића под насловом Из земље Хиришиме. Најзад, 1911, као засебна књижица, појавиће се и Кочићева Cуданија, коју су читаоцима годину раније већ предочими бањалучки Развитак и сарајевска Босанска вила. 
Кочић и Ћоровић били су највиђенији припадници политичких групација окупьених око Отащбине и Народа, а уједно и саборски посланици. Скарић посланик није постао једино зато што га је у томе спријечима опака болест, иначе његов угмед и значај у групацији око Сриске ријечи били су несумњиви. Преко сатиричких текстова ове тројице аутора у основи је могуће сагледати и цјеловиту политичку платформу српског кмуба у Сабору, бар у вријеме његове идејне и моралне монолитности, док га нису почели подгризати интересно фракционаштво и подривачка дјелатност разних нагодбењака, прдектера и фуртумаша, како су их с презиром и подсмијехом звали у то вријеме. Њихову борбеност и досњедност у отпору завојевачу ништа није могло сломити, ни беспоштедна цензура, ни прогони, ни тамновање. Али су, ипак, сломили њих; Кочић је сатрвен током, а Ћоровић непосредно након рата. Једино велемученом Скарићу вцасти нису могле ништа јер је њега штитио неповредив имунитет, онај од Бога, како је сам горкохуморно коментарисао сопствену претешку позицију са свог оптуженичког кревета. ${ }^{2}$ Наредна два цитата, један из Кочићевог уводника у Отаибини, Аруги из Ћоровићевог саборског говора, могу укратко Аа представе кьучна начела српске политичке борбе након анексије:

Ми у првом реду борбу за облигаторно решење аграрног питања не сматрамо никако ни вјерским ни националним, него једино социјалним питањем. Ми зато отворено устајемо против ага догод стоје на супутном становишту, тј. Аогод су за факултативно рјешење. Ми не питамо јесу ми те аге муслимани или православни или католици. Сви су они, које год вјере били, за нас аге и као такови начелни противници докле гоА они не постану облигаторци. Што је удес тако хтио, да је већина ага муслиманске вјере, томе нисмо криви ми. Што политика муслиманског емемента стоји претежно у рукама ага, ни томе нисмо криви ми. Што муслимански представници као аге ово чисто социјално питање доводе у везу са вјером и исламом, ни томе нисмо криви ми. Што пакташи пишу Аа су само српски кмети разбојници, а да су католички питоми као јањци, ни томе нисмо криви ми. Ми нисмо вјерски фанатици, и ако смо добри православци зато и не можемо мрзити друге вјере. Ми исто

\footnotetext{
${ }^{2}$ „Вемемучени Зембиљ ефендија имо је част ових дана да сједне на оптуженичку кмупу, односно Аа межи на оптуженичком кревету, због што се тиче онога, проњетос заплијењеног 'Зембиња'. Узевши у обзир да њега штити имунитет којег је добио не оА вмаде, него оА Бога, оА 'старог крвника, обуставњен је против њега Аањи процес. Е, мој Зембиьу, благо си га теби, каА ти уживаш таку слободу и имунитет ко ниједан твој земњак! Опет, ко ће ко Бог, оА Бога му тешко!“
} 42 (Skarić 1982: 117). 
тако поштујемо ислам као и католичку вјеру; и не боримо се против њих. Што ми морамо да се бранимо од католика као такви, узрок је једино, што су њихови свећеници агресивни и што би жељели да смо сви католици. Муслиманима се та вјерска агресивност не може пребацити, зато још мање имамо разлог да их нападамо. И стога овдје једном за свагда изјавьујемо, да ми против наших муслимана немамо ништа. Ми знамо да су они истог језика и крви, и да би требали, да је среће, да смо један народ, али кад наши муслимани хоће да буду анационацни, ми их не можемо симити да постану Срби; мада су то заиста по крви, језику и пореклу. Хоћемо и у томе да будемо миберални (Čubrilović 2016: 144-145).

Багателисати један народ који сачињава већину у земьи, запостављати га на свакоме кораку, сакривати историју и име његово преА рођеном му дјецом, унаказити му језик, гурати странце на све веће и мање поможаје у земьи, а његовим синовима бацити мрвице које иза њих остану, гонити га, глобити и, поред свега тога, очекивати од њега да буде задовољан - је ми то могуће? И ако се десимо када да је народ јаукнуо, вриснуо, да је покушао наћи одушка своме големом болу и јаду своме, онда су се громовници зачуђено погледиваци и питали се: откуда то и зашто то? И мјесто да су тражили узроке томе очајноме јауку и вриску у себи самима и у својим поступцима, они су - Аа остану прави преА свијетом - тражили их у некаквим утицајима са стране, и тобоже у нечијим агитацијама, узимајућ при томе у помоћ извјесне новинаре са микроскопски непримјетном дозом мораха у себи, који, знајући колико су дубоки џепови њихових господара, заборављаху на пословицу да је у мажи плитко Ано (Ćorović 1967a: 161).

Наши сатиричари нису бими бескомпромисни само према окупатору, беспоштедно су шибали и по свим домаћим изопачењима. Кочић је немимице изобцичавао жметодерску ${ }^{3}$ незаситост и опортунизам, којима су биле скцоне чаршијске газде, чак и поједине владике; Ћоровић је шибао по аморалним политичким пузавцима и руфетлијама, а Скарић жигосао сваки облик покондирења и напуштања изворних традиција, сматрајући куферашима и све оне домаће ьуде који раде противно народном интересу. С новостасалом ге-

\footnotetext{
${ }^{3}$ Ријеч кметодер сковао је, по свој прилици, сам Кочић и њоме означавао Аруштвене паразите, српске трговце „који су кмете, што су због откупа земње запали у безизмазно стање, економски поново заробьивали и упропашћивали“" (Popović 1936: 479).
} 
нерацијом школованих писаца, у датим историјским околностима, сатира је у Босни и Херцеговини природно и мако ухватика коријен; с једне стране, бима је ослоњена на народни менталитет склон смеху и исмејавағу (Кршић), као и на усмено књижевно насьеће, а с друге, на већ створену сатиричну митературу код српских писаца у Србији и Војводини. Мада је начелно смјехотворна врста, сатира код наречених наших писаца има извјесне специфичности у том погледу. Шта у одређеној ситуацији изазива смијех, питање је мичног карактера и колективних схватања. Смех је условьен многим субјективним и објективним факторима. У нашем хумору смехом је често прикривен бол. Зато је у нашој књижевности тешко одвојити хумористичко оА сатиричког, зато је у њој мање смеха ради смеха, а више ироније, ${ }^{4}$ хиперболе, инсинуација и инвектива, иза којих се осећа Аичност писца и његов гнев. Наш хумор је заиста 'зец кога гони пас патос’ /Dr Carl Lemcke/“. (...) Наша сатиричка књижевност, иако је у првом реду певаца политичку песму, коју Гете назива ружном песмом, није се ипак удаљика од практично-моралног задатка, који је већ Пиатон поставио свакој уметности (Kršić 2012: 106-107).

Треба нагласити да није ријеч о неком великом текстовном корпусу, али исто тако да је он веома драгоцјен, и као особена слика времена и као свједочанство о жанровском усложњавању српске књижевности у свом босанскохерцеговачком регионалном одсјечку.

\section{II}

Мало је примјера тако органски нераскидивог јединства политичког и књижевног дјеловања какав представьа случај Петра Кочића.

Кочић је сав свој раА, књижевни, као и политички, ставио потпуно свесно 'у службу својој растрганој и угњетеној отаџбини'. По природи пцаховит и осетьив на сваку неправду, Кочић је, чим је узео перо у руке,

\footnotetext{
${ }^{4}$ У свом чланку о босанској сатири Кршић врло прецизно одређује појам иронијског: „Иронија којом се нарочито воле Аа служе наши сатиричари продире у срж предмета који третира и раствара га изнутра. Она, наоко, прихваћа ствар, али само зато да у њој нагласи и открије њене слабе стране. Зато је она дубња и ефикаснија од обичне досетке и директне инвективе. Иронија је најјаче средство сатире; она рањава и сипа отров у рану. А^и, она се не може свуда употребити, она мора имати извесно морално оправдање. Чим се иронија употреби против појава које сматрамо у основи добрим и поштеним, она губи ефекат, нема катарзе и наместо сатире постаје персифлажа, у најнижем смислу“" (Kršić 2012: 107).
} 
осетио да и оно може да буде убојито оружје у борби с непријатеьем слободе и напретка народног (Kršić 2012: 107).

Без политичког импулса и набоја, он би остао осредњи писац етнографски засноване прозе, каквих је српска књижевност имала у већем броју на прелазу између Ава вијека. ${ }^{5}$ У том смислу, безмало цјелокупан његов опус карактеришу и неизбјежни сатирични елементи, аци се као чисте сатире издвајају Арамска једночинка, првобитно приповијетка, Јазаваи пред судом, и Арамски устројена приповијест Cуданија. Бројне сатиричне пробљеске саАржи и његов цикмус прича о Симеуну Ђаку, као и нека друга, мање позната приповједна остварења.

Кочићев нараштај српских приповједача из Босне и Херцеговине није имао за своје стварање у регионацном контексту непосредне умјетничке претходнике. Уз неколицину старијих сакупьача, од невоље писаца и ьетописаца, какви су Прокопије Чокоримо, Јоаникије Памучина и Гавро Вучковић Крајишник, они су имахи само родни језик и на њему створено богато усмено насьеђе, које су познавали аутентично, из прве руке. То 'само' је, очито, бимо и довоьно и пресудно. Колико је, рецимо, Станковићев Митке мирски сав успостављен на карактеристичном Аијалекатском говорном исповиједању, толико Кочићев Симеун Пејић Рудар, Ђак од намастира Гомјенице, умјетнички постоји искьучиво као чиста епска парадигма приче и причања. Неодољив је утисак да је сва стварацачка снага овог писца у језику, и то понајвише језику крепке Аијалекатске подиоге јеАног и географски, етнографски и антрополошки живописног краја, у коме је рођен, гдје је одрастао и коме се стално враћао као животној окрепи и умјетничкој инспирацији (Рopović 2017: 187-188).

Снага Кочићевог језика један је од најчешће истицаних момената у критичкој Аитератури, ${ }^{6}$ а у директној вези с њом је и сасвим особен хумор, који га издваја међу виђенијим представницима нашег мирског реацизма:

\footnotetext{
${ }^{5}$ Кочићев регионализам је у књижевном смислу од најплеменитије врсте. „Кочић је, наиме, регионалан писац у оном смислу у којем је то и Фокнер: његова историјска и географска регионалност представњају сужавање и изоштравање фокуса крајњих питања живота, надахнуће једне свеобухватне и потресне конкретности, 'чворновите и врлетне' конкретности која се сва изнутра крши и моми; Кочић није - као они који би хтели да га сведу само на социјалног или само националног писца - провинцијалац духа“" (Koljević 1966: 463).

${ }^{6}$ „За Петра Кочића је језик потпуно једно са ьудима и земьом, свет и неповредљив као и они. Понекад човеку изгледа као да је и само Кочићево дело, цемо целцато, межало негде у дубинама
} 
За разАику од Аруге Авојице својих маркантних приповједачких сапутника, Станковића и Ћипика, Кочић је, поред трагичног осјећања живота, једини од њих имао смисла и за хуморна обојења, а она су особито Арагоцјена у његовом дјелу као противтежа подигнутом и патетичном тону. Смислом за хумор он испуњава и своје јунаке, као видом њиховог подношења прилика у којима су се нашли. Чак и Аавидов обрачун са судом и 'представа' у Cуданији, са превасходно сатиричким усмјерењем, у својим порама прожети су чарима хуморног поигравања, као израза отпорних снага ьудске природе и народног смисла за шалу и у најтежим часовима (Milanović 2011: 231).

Инвентивно осмишьена ситуациона комика само је иницијални подстицај језичкој комици, којом је омогућен духовни тријумф Аавида Штрпиа ${ }^{7}$ у Кочићевом најпознатијем сатиричном дјелу. Јазавцем је Кочић сатирички бескомпромисно разобличио окупаторово нерјешавање аграрног питања и његову политичку злоупотребу у односима етничко-вјерских групација, али и инертност вођства српског покрета за црквено-школску аутономију према том истом питању. ${ }^{8}$ Исмијана је крутост судске администрације, разобличена аустријска пљачкашка економска политика и жигосани разорни (не)морацни утицаји западне цивимизације на патријархалну средину. Оштра критика аустријске културне и језичке политике, а поготово карикирање накарадног језика нове управе, ${ }^{9}$ што су биме важне теме његових саборских иступа, постали

тога језика, а он га је ископао као кип, и изнео на светлост дана и преА поглед света“" (Andrić 1986: 161-162).

${ }^{7}$ „Опчињен тим зАравњем духа и смеха, могућим бар на маргини мукотрпног живњења, Кочић је у Јазавиу микове суца, писарчића и доктора обезличио и подредио Аавиду. Они су заправо само декор и статисти маштовите бурлеске коју АавиА режира и води. Овим поступком драма је можАа жртвована Арамској освети, а дијалог и радња монолошкој Араматизацији једног ника. Али нам је зато Кочић дао Аавида Штрпца, његов дух у искричавим тренуцима озарености и духовног смеха из пуних груди. А то није ни мало ни безначајно“ (Koljević 1966a: 469-470). ${ }^{8}$ „Неки ме Аан, баш ће бити у прошли пазар, пита газда Стево: 'Признајеш ми ти, Аавиде, Аа си српски прекославни, школски, црквењски и ато-но-то...' О, тешке ријечи, крст јој ьубим! Прије би сломио језик него што би је изговорио. (...) Ја сам богме, велим, газда, мислио да ви тражите да царевина укине ову проклету трећину и десетину, а ви почели некакве будалештине збијати“" (Кос̌ić 2016: 97).

9 „То је једна одурна наказа, тешка и усиьена, често пута потпуно неразумьива, без гипкости, еластичности и звучности, тих битних особина нашег дивног језика. То је језик као наш, а није наш, наше су ријечи, ами језик није наш. Из тога језика не провијава дух нашег језика, то није језик који смо слушали и научили са мајчиних усана, који је краснији оА пјесме, језик Вуков и Ааничићев и наших нових писаца. Ову одурну наказу народног језика створили су странци и наши ьуди, Срби и Хрвати из Хрватске. Први су га, странци, научики само мексикацно, а Аруги, 
су и неизбјежни елементи ове сатиричне једночинке. Овај први умјетнички текст српске босанскохерцеговачке сатире, драматуршки заснован на траАицији народног глумовања, постао је врло брзо основни путоказ наредним сродним покушајима и остао, без обзира на недостатке, по свом значају, све до данас кмасична вриједност српске књижевности.

Колико и Аавид Штрбац, толико је и Симеун Ђак као мик носилац Кочићевог сатиричног духа, са истим правцем дјеловања. Непомирьиви противник свега што је окупатор Аонио у његово отечество, ${ }^{10}$ он с крајњим презиром гледа чак и на швапске лумере за градијерање ракије, а камоли да би пристао

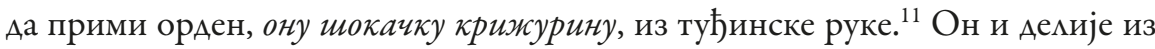
његове дружине стацно имају на уму древно пророчанство Книге староставне, које каже да ће настати пошьедња времена „и ммоги главни ьуди и сви отачествени аркијереји, због масник ајкука и царски бурунтија, постаће муртати и невјерници своје цркве и народа“. Ма и најмањи знак потпадања под туђински утицај за њих је аларм на узбуну и разцог Аа Аигну глас чак и против сопственог вмадике: „Боље да и то раде него да носе шкрљаке и да се по Бањој Ауци шајцају са швапским роспијама ко трбушати Аикота, срам га и стид бимо Кристова Аишца. И то ми је вмадика и један Кристов свјештеник“ (Кос̌ić 2016: 149, 131). Српска чаршија и њен газдиниук, већином трговачки, аршинциски и рачунцински, нису били честа мета Кочићеве сатире, али да умије да их веома успјешно учини предметом (под)смијеха показао је у мало познатој приповјеАној скици O проклете вечерашње вечери! Уобичајена кочићевска оштра сатира ту је замијењена необично благом пародијом, а баш поводом ове недорађене приповијетке намеће се неодољив утисак да је Кочић могао бити, да је којим скучајем стигао, успјешан писац и градских тема.

Ако је Јазавац пред судом најпознатија, онда је Суданија вјероватно књижевно најуспјешнија Кочићева сатира. И једна и друга очигледно показују Аа је писац у слици аустријског суда, који је и мично добро упознао, нашао најдјелатнији модец сатиричног представљања свеукупног стања окупације у

Срби и Хрвати, дошли су са прилично накарадним језиком, који се опет развио у Хрватској поА утицајем њемачког канцеларијског језика или граничарске команде“ (Кос̌ić 1986 III: 245).

${ }^{10}$ „Е, моја Ајецо, истрово је Швабо свијет, испоганио и превјерио. Ушла у народ некаква невјера и прокметство“; „Швабо, Швабо, жив се ти распадо, што нам отрова земьу и уби у свачем снагу и берићет“ (Кос̌іс́ 2016: 131, 146).

${ }^{11}$ „- Шта?! - врисну ја и одскочи Ава корака натраг. - Зар одма римити?! Шта је то и како то море бити? Зар је така права у ћесарокраља?... Нијесте се честито ни одморили у овој земьи несретној, а већ одма почели шокчити и римити! Зар је то ваша права; зар сте ви с таким редом Аошли у нашу земьу?! - сасу ја ватру на капетана“"(Кос̌ić 2016: 149). 
Босни и Херцеговини. Суданија тематски представља Аио аутентичног пишчевог затворског искуства из бањалучке Црне куће, па је тиме већ упечатьивија и умјетнички увјерьивија. Аикови у њој су далеко од сваке папирнатости, све их одреда безрезервно прихватамо као стварне животне актере и као таквима им и вјерујемо. ${ }^{12}$ Мотивски је слична Јазавцу, али док је он само један интензиван монолог, она је, рекао бих, драматичнија; у радњи, суђењу које су у затвору инсценирами хапшеници, већином Кнежопољци, учествује више ьуди од којих сваки своју улогу одиично игра. 'Суданија', иако на местима показује извесне некњижевне особине (развученост), пуна је изврсно погођених карактеристика, оштрих карикатура службеног језика б-х. судова и правог хумора (Kršić 1936: 490).

Суданија је драмски утврђена као Авострука игра: с једне стране се, као Ајеца, затворени Кнежопољци играју пародирајући аустријско судство, Аок се, с друге стране, озбиьно правно едукују за стварна сопствена суђења, потпуно свјесни да „брез науке, брез разније маривета, прискочица и, Аа речемо, Аоскочица, не мереш данас никуд макнути“ (Кос̌іс́ 2016: 239). Та врста Авострукости подразумијева и Авије врсте језика, онај који се пародира и онај којим се исказује сопство.

Радња је сведена на акцију ограничену пародирањем, а израз на ријеч, језик. Пародирање искьучује Араматичност. Измјена Аица и сцена увјетована је основном пишчевом намјером. Араматичних сукоба нема, јер се без снажне акције не могу испољити. У 'Суданији' се прати ток процеса само као основа на којој почива хумористично и сатирично пишчево пародирање. Овакав поступак је нов у Кочићевом књижевном Ајелу. Примијењен на значајној теми Аао је сатири оштрији израз и дубње значење (Ćorić 1966: 482).

\footnotetext{
${ }^{12}$ Тако се, рецимо, вјерује ријечима Косте пуцера којима увлачи писца у затворску суданију, а које из затворске перспективе оцртавају свеопште народно расположење под окупацијом: „- У истрази су пуцери Србови, у осуди исто Србови. По собама су команданти Србови. Турци неће ништа да буду. Они мрзе све што је каурско. Море бити да ми више мрзимо, али се свега примамо - какше је одати и нешто радити него чамити у ћелији. Католици су туњави и спметени, па и’ не мећу ни за што. Они се само моме богу... Има у мене јеАан у соби за крађу - покро цркву - па само што чата некакве зАраве Марије! Ћутьив је, не говори ништа и не прича ништа. Уздише само и мисли на осуду. Ми Србови јок! Тешко је и нами, али се отимамо и бранимо шалом и егленом...” (Кос̌ić 2016: 236).
} 
Иначе, круг пародираних феномена у Суданији ${ }^{13}$ подударан је с оним из Јазавца, само што је смијех који доноси ова најдужа Кочићева приповијетка без икаквих примјеса, чист и ведар, и незАобив, и народски здрав у тој чистоти.

\section{III}

Животна прича Саве Скарића једна је од најтрагичнијих у повеликом низу осујећених стваралачких биографија за које зна историја српске књижевности. Рођен је 1878. године као изданак једне од најстаријих и најпознатијих српских сарајевских породица и у родном граду је довршио шест разреда гимназије, након чега уписује студије фармације у Загребу, које ће дотјерати Ао Аипломског испита, кад се нагло и тешко разболио од реуматизма зглобова. По повратку у Сарајево, 1904, са свега двадесет седам година, пада у постеьу и остаје непокретан све до смрти 1909. године. Скарић се и као писац јавио са болесничке постеье једном дугом, трогодишњом, серијом текстова у сарајевском мисту Српска ријеч, започетом августа 1906. чианком Политички зерзеват, који је потписао псеудонимом ІІумбушчија. Тај псеудоним остаће му трајно један од надимака, поред оног познатијег Зембиљ, како се зваца његова стална рубрика, феьтон у Српскојријечи. Зембиь је ријеч која означава торбу за ношење намирница, плетену од размичитих материјала (платна, коже, трске, рогоза), која је у старије доба бима позната колико касније германизам цегер (цекер). Џумбус је пак мом, нереА, русвај, хаос, а онај ко га чини јесте џумбушчија. Ови турцизми су веома знаковити каА је у питању Скарићево књижевно-новинарско стварацаштво. Његов феьтон, који је Српску ријеч за три године изцажења чинио најтиражнијим политичким гласилом у Босни и Херцеговини, фигуративно и јесте био сатиричка торба, у коју је аутор сваке

\footnotetext{
${ }^{13}$ „Једноставна по основном запмету, Суданија је у изведби Кочићево најсложеније дјело (стиц, реторика, елементарни облици, идеје), пандан цикмусу приповијеАака о Симеуну Ђаку. Помињана је генетичка веза с Аостојевским (Вучковић) и Горким (З. Вуловић), потенцијали кафкијанских и пирандемовских мотива (Бегић, Аеовац); изван спора за све који су писали о Суданији је - да је сатира и пародија (додао бих: можда и својеврстан пастиш судских аката ауторовог времена и његовог искуства са судовима). Уза све то, наговјештава нове стране Кочићевог приповјеАачког Аара, захват у модерна времена као времена прерушавања, сталне глуме у службеним и приватним (Аичним) улогама“" (Ivanić 2017: 197).

${ }^{\text {вва }}$ навод узет је из Иванићевог текста који представња поговор најновијем издању Кочићеве Суданије из 2017. (Кос̌ić 2017). Оно је занимьиво утолико што саАржи и текст приповијетке и његову прерађену драмску верзију у форми Комедије у 4 чина с певањем. Текст комедије штампан је на основу рукописа насталог током ьета и јесени 1915, у вријеме Кочићевог боравка у Аушевној болници у Београду, а у односу на приповијетку саАржи извјесне измјене.
} 
суботе трпао разнолике актуелне зерзевате, чинећи прави иумбус строгој и крутој аустроугарској управи.

Сатиричке 'зембиье' објавьивао је пуне три године, све до почетка августа 1909. године, а били су прожети снажним исмијавањем политичких, социјалних, бирократских, аци и морамних аномамија свога времена и своје средине. (...) Скарићев сатирички феьтон био је близак сличним текстовима Икије Огњановића Абуказема (који су засновани на политичком и друштвеном животу Новог Сада у осамдесетим годинама 19. вијека), те нарочито Радоја Аомановића и Бранислава Нушића (који су усмјерени на исмијавање политичких и друштвених аномахија у Београду на почетку 20. вијека). Смјехотворни поступаку Скарићевим феьтонима почива на језичкој комици, у којој долази до изражаја разорна иронија, сарказам и персифлаже, а затим и вјешти језички каламбури, изреке, досјетке и пословички искази, сновидне фантазије и сл. (Maksimović 2013: 73-74).

Скарићево рођење није нимамо случајно памо у истој години кад и аустроугарска окупација Босне и Херцеговине, био је то готово судбински знак за човјека који ће сав свој живот посветити борби против окупатора. Још као гимназијалац, заједно с Васиьем Грђићем, Миманом Сршкићем и Живком Њежићем, биће оснивач тајног политичко-књижевног друштва Cрnска свијест, које ће 1896. покренути и истоимено гласимо, илегамно митографисано на тавану Скарићеве породичне куће. Као израз свјесне националне акције схватао је и сарадњу са Српском академијом наука у Београду, гдје је слао народне пјесме забиьежене од српских сеьака из околине Сарајева. КаА почиње сарадњу са Српском ријечи, он је већ сасвим зрео национални борац и идеолог, уз Петра Кочића, Светозара Ћоровића и Риста Радуловића најзначајнији кога смо тада имали међу ьудима од пера. Скарићеви сатирични фељтони од истог су mеста као и сатире Кочићеве, записаће Јован Кршић, критичар који је у периоду између два свјетска рата понајвише урадио на афирмацији овог писца, напомињући како је у своје доба као сатиричар био популарнији, а почесто и оштрији од Петра Кочића. Као и Кочић, био је изразито језички колоритан и изразито критичан према кварењу и кваритељима језика. ${ }^{14}$

\footnotetext{
${ }_{14}^{14}$ „Неки дан читамо у Штадлерову таламбасу 'Hrv. Dnevniku' ријечи 'Bosnoj' и 'Bošnjaci'. Трећи падеж од ријечи Босна је Босни, а не Босној, а народ у Босни по земьи се не зове Бошњаци, него Босанци. Именом Бошњак маџарски грофови називају своје коње; коме је мерак да буде адеш
} 
Прије Кочића и његових иступа у одбрану народног језика (у Сабору 1910. и у Отаибини 1912), Скарић је подвргао жестокој критици накарадни језик досељене, куферашке администрације коју је Аустрија увозика из својих земања и која је своје приучено знање нашег језика - чудну мјешавину славенских језика и њемачког - симом административног апарата, свуда уводима: у књиге, уџбенике, новине, законе, наредбе. Као сваки стварамац, Скарић је био свјестан да је језик све беживотнији што је Аање од својих природних извора у народу. Писао је народним језиком, аргоом старог Сарајева, његових махама, сијема, чаршије - јер је у њему осјећао живот, аутентичан израз домаћег живота, couleur locale, осјећао снагу и животворност народног духа и у њему спонтаност и неуоквиреност живота, коју је власт прогоника, хтјела Аа затре. Народном језику, живом, творачком а илегалном језику, он је Аао карактер политичке опозиционалности (Đuričković 1982: 14-15).

И кад је бивао политички убитачан, овај рођени козер никада није био једак ни отрован, то је бимо страно његовом отвореном духу. Његови сатирички узлови (Кршић), ефектни каламбури и искричави парадокси редовно одишу простодушном веАрином и маме зАрав смијех.

Вријеме у коме је стварао бимо је необично политички згуснуто, а његово фељтонистичко Ајело обухвата га у цијелости, од царинског рата против Србије, преко анексионе кризе до вемеиздајничких процеса и вјерско-политичких трвења у Босни и Херцеговини. Народски човјек до сржи, он је мислио народну мисао и изражавао се како је то човјеку из народа било најразумьивије, постајући тако својеврсна политичка школа своје средине и свога времена. Примали су га једнако отворено и писмени и неписмени, а многи се Сарајмија, кажу, описменио само зато Аа би сам могао читати Зембиь-ефендијине написе. ${ }^{15}$ Његов политички програм био је непомирьиво антикуферашки,

с доратима и ђогатима, нек му је сретно. Ето, јадна вам мајка, колико познајете ово наше парче земье, па бисте још хтјели да вам је џабе Босне! Уснила се кока у хамбару..." (Skarić 1982: 35).

15 „Обичне, просте ьуде, политички несвјесне, сељаке, занатлије, домаћице, претварао је у помитичке манифестанте: у болницу, гАје је межао, долазили су му као на политички збор, Аа кажу своју и чују туђу, да размијене информацију, да његовом 'зембиьу' додају и штогод своје, а Аомаћице, којима то није примичимо, сламе су му пите, урмашице, баклаве, кадаифе, гурабије... Као гуслар, имао је своју публику, као вођа политичке странке - имао свој дебатни кмуб, као народна пјесма - његов 'зембия' је ишао од уста до уста. УзАрмавао је равнодушне, политички метаргичне, пов ачио у народу јасну минију, био вододјелница. Засмијавао је, али и политички просвјећивао: духовитим афоризмом, каламбуром, сликом, алузијом, анегдотом, фантазијом 
програм очувања домаће слоге и његовања отпора погубном туђинском утицају сваке врсте.

Куфер је симбом империјализма и грабежљивости. У њему је Швабо у Босну донео неправду, насиље, маж, моду и окупацију. Насупрот свему томе, Скарић ацармира сву морацну отпорност патријархацног света. Он је био конзервативан, али није био реакционаран. Помитички, он је имао једну основну мисао коју је свуда у својим сатирама пропаговао: солидарност с муслиманском браћом. Он је веровао да се дубока мржња муслиманских маса против Швабе може искористити као позитиван борбени фактор у српској ослободимачкој борби. Скарић је својим сарајевским језиком, пуним мокалне фразеологије и типичних турцизама, као и својим отвореним и слободним антиаустријским и антиклерика ним ставом знао да дирне у најтањи живац муслиманских маса, које су му биме најоданији читаоци (Kršić 2012: 119).

Куфераш(и) је, дакме, централни топос његове сатиричне прозе, ријеч коју је он унио у српски језик. Тај појам Скарић по потреби веома мако претвара у жив, изразито гротескни мик, чудну незаситу неман, која се у Босни Аржи нарочитог јеловника. ${ }^{16}$ Позван да у јеАном од својих феьтона објасни значење ријечи коју је сковао, аутор то чини веома прецизно:

- отварао је очи, политички описмењавао у очигледној настави свакодневног живота“ (Đuričković 1982: 9).

16 „- А то била добро вечера. Појел сам око сто педесет српских и турчинских мехкишов и прдектеров и преко Авјеста педесет шпанише Јуден.

- Ја, тако ти носа Анте Старчевића, хер куфер, који ти је онако најбове шмеково?

- Тако ми нос од Старчевић, најслаткији ми је бил један Србин, за кога су сви мислили да је оскоруша, а он је бим сладак как ти урмашица“" (Skarić 1982: 195).

$\mathrm{O}_{\mathrm{A}}$ тачно шездесет презимена куферашких породица које су с Аустријом дошле у Босну и Херцеговину, Скарић је скнадио и својеврсну куферашку 'химну':

Аутмик, Сумрек, Јеминек,

Хасил, АрнолА, Земанек,

Ганзел, Штимкер, Шустер, Фабер,

Митермајер, Хубер.//

Биберауер, Есигман,

Карба, Рота, Остерман,

Брезаноци, Нађи, Пешек,

Скацем, Фишер, Јежек.//

Штробл, Коко, Расинец,

Зердахели, Моравец,

ГотфриА, Кајзер, Хампц, Браздил,

52 Штумбергер, Тужим.// 
Куфераш је сваки онај, који је дошо с куфером у Босну, живи од овога народа, а жели му нешто друго него што народ сам себи жели. Онај човјек, опет, који у идеацима овога народа налази и своје идеале, није куфераш нити може бити, па ма он био чак из Чина или Мачина. Исто тако море бит куфераш и онај који се родио у Босни, па чак коме се и шукунђед родио овдје, ако ради куферашки (Skarić 1982: 163).

Посебно је био непомирьив према погубној, зАруженој и врло агресивној акцији франковаца и језуита под високим покровитеьством режима и ватиканске врхушке. Ту је био најотворенији, аци и најдуховитији. Омиьена мета био му је врхбосански надбискуп Јосип Штадмер (1843-1918), главни носимац офанзивног католичког прозелитизма: „Сарајево је добило четири нова трамваја и једног бискупа. Трајвани или транваји ће служити за преважање ьуди из града на штацију, а нови бискуп ће служити за преважање душа из православне и исламске вјере у римокатоличку“ (Skarić 1982: 96). У сталној је полемици са сарајевским Хрватским дневником, ${ }^{17}$ чији је тадашњи уредник најповјерьивији Штадмеров човјек, Керубин Шегвић. Овако, у Скарићевој интерпретацији, изгледа Дневников деманти на вијест о покрштавању једног сарајевског Мусмимана: „Није истина да је гореспоменути Омер прешао на католичку вјеру, већ је напротив, истина да је католичка вјера прешиа на Омера“" (Skarić 1982: 82). Шибао је све што је однарођено, једнако на све стране - и хрватске културтрегере, експоненте аустријске политике, попут Косте Хермана, Бубоја Алустуша и Ћире Трухелке; и режимске ьуде међу српским интелектуаццима, какви су били Ђорђе Настић и др Аазар Аимитријевић; и, нарочито радо и често, политичко мицемјерје Адемаге Мешића и његово подвођење Муслимана Аустрији. ${ }^{18}$ Скарић није имао неки систематичан политички програм према

Фрајман, Рубал, Томоруг, Шренци, Хамер, Коч, Пофук, Игл, Шаден, Кон, Наковски,

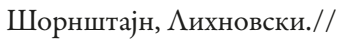

Кубеш, Урлеп, Павелка, Аинкеш, Фелдшар, Колејка, Морел, Хофман, Ендер, Штенци, Ватман, Брајер, Хајнц.

${ }^{17}$ „Штадлерово кмепетало, звекетало, тандркало, чинчикало, зврка, тремпе, таламбас, и како га све до данас не назвасмо, наш дични 'Hrvatski dnevnik'“ (Skarić 1982: 108).

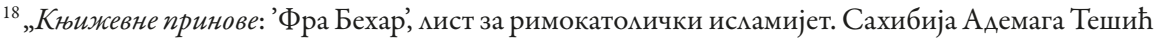
у Мешњу. Корице додуше зелене а садржај црножут. Сретан почетак! Фањен Исус, олсун!“ (Skarić 1982: 213). 
коме би усмјеравао своју сатиричке написе, он је Ајеловао отприлике Ао прилике и обарао се на појаве онако како су му се наметаце. Кад окупаторска цензура преврши сваку мјеру у санкционисању манифестовања српског национализма, он ће се окомити на њу, ${ }^{19}$ Аа би одмах потом ударио на већи дио наше млађе интелигенције, која презире ситни национални раА, а патриотизам сматра нечим несавременим и недостојним интелигентна човјека. Политичка превирања у Србији пратио је пажьиво, ами их је ријетко коментарисао у свом Зембиљу, свјестан да је свака загледаност на ту страну истог трена постајала оружје у рукама аустријске пропаганде. Поводом једне од скупштинских криза, уочи саме анексије, јетко препоручује како би се она

могма ријешити да им ми из Босне позајмимо мало окупације. Бојсем каА би се малко окупами овако ко ми, да би се мамо размадими од партизанске ватре и кахпилука. Аустријска штампа нас угњави о некаквој српској пропаганди у Босни. Та шта ће нам српска пропаганда кад смо Срби, него би требало у Србији повести српску пропаганду, пошто је тамо много раширенија старорадикалска и младорадикацска народност него српска (Skarić 1982: 217).

Овај горкохуморни коментар убједљиво декларише Скарића као расног сатиричара, писца који је умио да из дневнополитичког повода извуче постојаније и далекосежније истине.

\section{IV}

Светозар Ћоровић је био морамна осовина и само срце омцадинског националног покрета у Мостару, који је истовремено био и културни и политички. По речима Атанасија Шоле, Ћоровићевог друга из младости, Светозар се 'спомиње само у улози књижевника, а заборавьа се његово дело као национацисте и покретача многих национално-културних и чисто

19 „КаА је Акурти испитивао на расправи једнога оА 'вемеиздајника', прво га је упитао:

- Јесте $и$ ви Србин?

- А смије ми се уопће бити Србин? - упитао је оптужени.

-Та смије, али не смије толико - одговорио му је Акурти.

$\triangle$ а се узмогне опредијелити, колико је који Србин, мораће Раух измислити какав 'србометар', справу за опредјеьивање Српства код појединих ьуди. Рецимо, справа ће бити подијеьена на сто деређа, ко термометар, и до 37.5 биће слободно бити Србин, а чије Српство прећера преко 37.5 деређа, на вјешала с њим. Вала га Србин није научио србовати на мискац, ни мање од

54 сто гради, па га ти мјерио не мјерио!“ (Skarić 1982: 289). 
политичких акција у својој средини, где је његова необична инвентивност Аолазила до изражаја и ствараца многобројне резултате. Све те послове Ћоровић је радио анонимно. Поред окупьања сарадника око Зоре, он је био у почетку душа часописа; чак првих година редакција и администрација бима је у Гуслама ики у Светозаревој магази.' Његовом заслугом тадашња српска влада у Београду на време је обавештена о покрету сеобе Срба из горње Херцеговине, 1902, и покрет је на време паралисан затварањем границе (Radulović 2010: 336).

Као посланик највише се ангажовао против аустријске прохрватске просвјетне политике, провођене преко уџбеника, сматрајући такав облик покушаја однарођења посебно опасним, једнако и за Србе и Муслимане ${ }^{20}$ :

\footnotetext{
${ }^{20}$ Ћоровићеви посланички говори на појединим мјестима Аају најбове примјере његове политичке сатире. Критикујући Хорватинов уџбеник матинског језика и вјежбанку за њемачки језик, чији је аутор био извјесни Hinko Scheidele, он у Сабору, на одушевњење већине, импровизује хипотетичну, изузетно духовиту мини-Арамску сцену, која би могла Аа се замисли у било којој ондашњој муслиманској породици. Актери су син гимназиста, који наглас спрема школске мекције, и неписмени отац, који то слуша:

„- Ама шта то учиш толико? Шта је то, синак? - пита отегнуто.

- Patria nostra est Croatia.

- Па шта се ту, бива, каже? Протерџумани ми то!

- Аомовина је наша Хрватска.

- Е, ја ти ту ништа не анкајишем - вели стари и врти главом. - То је, џанум, нека јалан-књига. По нашој старој књизи и јазији наш је вилајет Босна, а то је име, бели, и Швабо укабулио.

Па се попридигне мало и опет заврти главом.

- Јаман-књига, јалан-књига - каже. - Аај, читај другу!

Аијете узима Scheidelinu Њемачку вјежбеницу и чита из ње:

- Ја идем данас у цркву. Ја сам радо у цркви.
}

- А шта ћеш ти у цркви, несретни сине? - пита стари и оштро га гледа. - Зар си заборавио џамију?

- Старо вино ми је Араже него ново - чита мали дање, не слушајући старога (У саборници опћи смијех и пьесак.)

- Шта? Шта бре? Вино?

- Ако добијем о Божићу од оца нови шешир, бићу врло добар и марьиво ћу учити! - опет чита мали.

- Ама, болан, јеси ми ти муслиман, шта ми си? (Смијех, одобравање и пьесак.) Шта је то амлах ризасићун?

- У школи учимо, у цркви молимо, у врту ћемо играти. Кад продам јаја, купићу свињче.

Аијете није још све ни договоримо, а чибук очев пуче му о главу и кула се разби у комаде. (Размагање говорника прате сви посланици уз непрестани смијех и одобравање.)

- Зар ти мени крмка у кућу, домузине један? - виче стари ьутито бацајући књигу кроз пенџер. - Зар те томе у школи научише?" (Ćorović 1967а: 193-194). И овај фрагмент довољан је Аа преАстави јединствену Ћоровићеву приповјеАну и драмску наклоност према темама из живота херцеговачких Муслимана, поготово након окупације. 
Аа споменем само матинску вјежбеницу Мирка Аивковића, у којој о Србима ни спомена нема, иако смо рођена браћа Хрватима; ту се хотимично избјегава да и једно хрватско дијете спомене, макар и узгреА, српско име, Аок наша дјеца непрестано морају на свакој готово страни читати: Croatia gloriae patria, Bellica gloria antiquorum Croatarum nota est, Zagrabia caput et magnum decus Croatiae est, итд. (...) Ако ћемо ce кумити, нећемо се гулити, и као што нијесмо ради никоме симом да намећемо своје име, тако нећемо дати да се на овако подац и недостојан начин намеће нашој дјеци друго име осим српског, макар оно и братско бимо. Стари су нам умирали бранећи то име; затреба Аи, умираћемо и ми, а нећемо га изневјерити (Ćorović 1967a: 192-193).

Исидора Секулић оспорила је Кочићу сатирички таменат, бранећи то неубједњивом тврдњом да „човек са култом бола и етиком и естетиком бола, није заправо сатиричар“ (Sekulić 1959: 71). Иако се мањак сатиричке предиспозиције свакако не би могао приписати Кочићу, таква тврдња у Ћоровићевом случају не би била дамеко од истине. За праву сатиру њему је недостајала јача Аоза самосвојног хумора, а то што се ипак окушао и у том жанру, ствар је његовог схватања дужности јавног националног дјелатника и својеврсни налог времена. ${ }^{21}$ Пародијско-сатирични списи свакако нису најбољи дио Ћоровићевог митерарног опуса, али пародијско сликање домаћих нарави и друштвених

\footnotetext{
${ }^{21}$ Ријеч је о времену које је презасићено разноликим идеолошким сукобима на свим могућим релацијама и писци су преА сталним изазовима некаквих обрачуна, тако Аа и они крајње нескмони сатиричком жигосању не могу понекаА да одоле таквим изазовима. Најочитији такав случај представьа реакција Алексе Шантића у виду алегоријско-сатиричне пјесме Из Бир Хащи-Бобина долафа, изазвана сукобом Народове групације, чији је члан био, са власницима и уредницима мостарског Сриског вјесника, браћом Радовић, Аушаном и ВАадимиром. Ево како, у кратким оАломцима тог стихотворенија, изгледа меки миричар Шантић у ставу борбеног сатиричара:

Е баш ти ја немам нимало игбала!

На мене се дигла велика авала:

Ава дилбера, демек, биринџи јунака,

Из махаме старе, Камханског сокака,

Ава икума, џанум, што пишу џериде,

А што су им, бива, веома шефиле, -

Ава Аилбера, аман, Алија и Ауран,

Што напамет знаду и ћитаб и куран,

На четири стране пушћали авазе,

Искупили, побро, паше и кавазе,

Па ти меџиис Арже и све што је горе

56 О Бир Хаџи-Боби подједнако зборе (...) (Šantić 2006: 166, II).
} 
изопачења, какво је дато у Барону из Аангубице (1901), Женидби Пере Карантана (1902) и Записуима из Кисјељака (1902), ипак је ближе природи његовог талента неголи сатирично изобличавање аустроугарске окупације у феьтону Из земље Хириииме. Овакав суд, нешто строже изведен са становишта цјелине опуса, могуће је и ублажити ако се као критеријум узме првенствено временски контекст настанка поменутих дјема:

ОА блаже или оштрије пародије наших разцичитих друштвених средина Ћоровић је, међутим, ишао и до сатире наших општих политичких прилика и нашег положаја под аустроугарском окупацијом. У феьтонима Из земље Хиришиме он је показао несумњив сатирички дар и, опет без обзира на претјераности и намјештеност, врло инвентивно пародирао аустроугарску политику у Босни и Херцеговини, а та живост и инвентивност његовог сатиричког изобличавања огледа се најбоље у многостраности и вјештом мијењању перспектива из којих се уобличује слика стварности (Milanović 2011: 110-111).

Ћоровићев сатирични феьтон амегоријски је исприповиједан као јединствен низ шест кинеских прича у форми успомена једног путника, а потписан је псеудонимом $C$. Николајев. ${ }^{22}$ Алегоријска Хиришима веома мако се већ у први мах препознаје као пишчева окупирана отаџбина, његова варијанта Cmpaдије, при чему се неодољиво намеће помисао о јаком утицају Аомановићеве алегорично-сатиричне прозе. То је земьа кукања, стењања и уздисања, земьа чији је народ без права гласа и сатјеран у карантин, да не би сметао господарима, поданицима дичне усрећитеьке Ај-хунг-лунгије. Иако стриктно алегоријски заодјенуте, Ћоровићеве инвективе су веома директне, без финеса и нијанси. Аа би појачао слику посуновраћеног стања које је донијела окупација, писац ће се послужити гласом једног од главешина усрећитеьске империје, који се вајка на незахвацност Хиришимаца:

Неблагодаран су народ они!... Ми им очистики земьу и изравники је као Аа је пожар опалио, ми им шуме сасијекми, да их мање громови бију и провале облака попцавьују, ми им изнијели из кућа све што су имаци, да им је шире у њима, узели смо им новце да буду безбрижни, стоку смо им растријебили,

\footnotetext{
${ }^{22}$ Ћоровић је иначе користио више размичитих псеудонима. Овај је скован као патроним, јер се пишчев отац звао Никола. Вјеродостојност ауторства потврђује сам писац у једном писму ьуби Стојановићу, а доказује је и његов ммађи брат ВАадимир, у књизи Босна и Херщеговина: „У Народу, пореА Ристе Радумовића, који је био главни уредник, Светозар Ћоровић био је један од главних сарадника, који је имао много успеха са својим епиграмима и сатирама Из земље Хириииме“ (Ćorović 1924: 54).
} 
Аа их не буди својом блеком и риком, синове им гонимо у свијет да мање код куће једу и троше, наше ьуде доводимо да их науче радити и слатко јести и, помислите, након свију таквих бцагодети опет се ьуте на нас и криво им... Пхи!... Поган народ!... (Ćorović 1967: 236).

Ни најмањи смијешак не изазивају ове ријечи; из њих само јасно одјекује онај чемерни Аавидов јаук захвалности, упућен Царевини, која га је ослободила свега. И Хиришимци су, као и Аавидова њивица, ни царски ни спахијски, без игдје икога и ичега, додуше с великом привияегијом свакодневног уживања царског бурмута, од кога су и душу искијали.

Сатирични ефекти најзаоштренији су у средишњем дијелу феьтона, чији је наслов Хиришимски теферич. Ту је и централно сижејно чвориште, односно тренутак објаве закона о слободама, којим је царском мимошћу удостојен хиришимски народ а који чита великаш Биникико, чије је име могуће прочитати и као пародирано презиме барона Исидора Бенка, главног Кахајевог сарадника и једно вријеме цивилног управника земье. По том закону, између осталог, „слободно је отворити уста при јелу, иначе Хиришимци морају ићи стиснутих уста“. Исто тако, „пиакати над мртвацем слободно је, друго плакање је забрањено, јер је уперено против вмасти и постојећег поретка“23 (Ćorović 1967: 249). Пародијско-иронијски укмон овдје је додатно појачан хиперболом, основним механизмом Ћоровићеве сатире, у чијем кориштењу писац повремено губи функционалну мјеру. (Иначе, честа је употреба и карикатуре, присутне каткаА већ и у именима актера, какав је случај, на примјер, с царским службеником чије је име Ћушћуко.) Писац није пропустио да се дотакне и својих омиьених тема, осјетьивих питања пропагандно писаних школских уџбеника и преименовања српског језика, коме је за ову примику смишьен назив кукувратски. ${ }^{24} \mathrm{Y}$

\footnotetext{
${ }^{23}$ Како изгледа суђење по овом закону, предочено је у дијелу феьтона под насловом Пресуда у Хиришими: „По параграфу 8. крив је, јер наговара тице Аа могу пјевати, буни их против вцасти. Иако у закону изриком стоји Аа се пјевати смију само богоугодне пјесме, Симимајо се није хтио ни осврнути на то, а добро је знао да тице нису научиме пјевати богоугодне пјесме. Наговарати их да пјевају Аруго, па још у некаквој плавој слободи, то је Арско и може се свакојако тумачити. $\triangle$ а су тице биме муде па га послушале, онда би свака пјевала шта хоће, дигла би се граја до неба и нико жив у Хиришими не би могао заспати. Морала би држава да их оружјем, манцима и затвором умирује, а то би тек опасно било, јер би могло Аоћи до врло крвава сукоба између власти и тица“" (Ćorović 1967: 257).

${ }^{24}$ Као и Кочић и Скарић, тако и Ћоровић исмијава накарадност земаљског језика, што се може уочити готово коА свих српских писаца тога времена. Ево само јеАног карактеристичног примјера куферашког говора из приповијетке Под авором Радована Перовића Тунгуза: „Особиту ми част чини такав поћудан упит при овому мојој маленкости усрдному пријему од ваше стране у господскому вам дому. Акопрем ми је човјечански дужност и ионако вас, као велеуважена го-
} 
поглавьу Ћушћукин сан, финаму свог сатиричног фељтона, писац Ћоровић није одоцио осветничком изазову који је понио Ћоровића политичара и невољног поданика Монархије. Успавао је свог Ћушћука, угледног достојанственика Ај-хунг-лунгије и дао му Аа усни страшан сан: како су Хиришимци постали господари у сопственој земьи и како његово достојанство, као и привикегије, не вриједе више ни пребијене паре. Измучен тако грозоморним сновиђењем, у тренутку буђења смогао је снаге тек да завапи: „Боже, дај прије мени смрт него Хиришимцима владу у руке“ (Ćorović 1967: 266). Нема сумње да је баш оваква поента бима веома важан разцог успјеха Ћоровићевог сатиричног феьтона код читацаца.

\section{Извори}

1. Kočić, Petar (1986), Sabrana djela Petra Kočića I-IV, Banja Luka - Sarajevo.

2. Кочић, Петар (2016), С планине и испод планине и друга проза, јубимарно изАање поводом стогодишњице смрти Петра Кочића (приредили Аушан Иванић, Вања Шмуља и Споменка Кузмановић), Бања Аука: Народна и универзитетска библиотека PC.

3. Кочић, Петар (2017), Суданија; Суданија: Комедија у 4 чина с певатем (приредиме Вања Шмуља и Споменка Кузмановић), Бања Аука: Народна и Универзитетска библиотека РС.

4. Скарић, Саво (1982), Изабрана дјела. Зембиљ, мала имаскара (приредио Аејан Ђуричковић), Сарајево: Свјетлост.

5. Ćorović, Svetozar (1967), Sabrana djela. Knjiga IV, Sarajevo: Svjetlost.

6. Ćorović, Svetozar (1967a), Sabrana djela. Knjiga X, Sarajevo: Svjetlost.

7. Шантић, Алекса (2006), Сабрана дјела / Пјесме. Книга друга, Гацко: АОБ.

\section{Аитература}

1. Andrić, Ivo (1986), „Zemlja, ljudi i jezik kod Petra Kočića“, Sabrana djela I. Andrića. Knjiga trinaesta, Umetnik i njegovo delo. Eseji II, Sarajevo.

2. Благојевић, Михаимо (1936), „Кочићево доба (1876-1916)“, Преглед, Сарајево, св. 153, књ. ХII, гоА. Х.

сподина и пријатеьа високе вмаде, посјетити, то толико прије сам се морао поспјешити да вам ту Аавно жеьену подворбу порабим у ових згодах, каА су у наших окупираних провинцијах настала срећна доба препорођаја под узвишенијем скиптром његова апостолског величајнства нашег преузможног господара ћесара Франца Јозефа Првог... (Perović 1988: 25-26). Ништа Аруго не би могло толико живо представити предстојника Баруха као странца у Херцеговини комико овакав језик. 
3. Ђуричковић, Аејан (1982), „Хумористичко-сатирични феьтон Саве Скарића“, предговор у: Саво Скарић, Изабрана дјела. Зембиљ, мала и маскара (приредио Аејан Ђуричковић), Сарајево: Свјетлост.

4. Иванић, Аушан (2017), „Усуд Суданије“, поговор у: Петар Кочић, Суданија; Суданија: Комедија у 4 чина с певатем (приредиме Вања Шмуьа и Споменка Кузмановић), Бања Аука: Народна и Универзитетска библиотека РС.

5. Koljević, Svetozar (1966), „Kočićeva Krajina“, Putevi, Banja Luka, 5, XII.

6. Koljević, Nikola (1966a), „Duhovni trijumf Davida Štrpca“, Putevi, Banja Luka, 5, XII.

7. Kršić, Jovan (1936), „Smisao književnog dela Kočićeva“, Pregled, Sarajevo, sv. 153, knj. XII, god. X.

8. Кршић, Јован (2012), „Босанска сатира“, у: О српској књижевности у Босни и Херцеговини (приредио Аејан Ђуричковић), Бања Аука: Матица српска.

9. Максимовић, Горан (2013), „Козерски смијех“, у: Заборављени књижевници. Книжевноисторијски огледи о скрајнутим писиима српског 19. вијека, Пале: СПКА Просвјета.

10. Микановић, Бранко (2011), Студије из српске књижевности /Светозар Ћоровић. Алекса Шантић. Петар Кочић/, Паме: СПКА Просвјета.

11. Perović Tunguz - Nevesinjski, Radovan (1988), Gorštakinje, izbor iz proze, Sarajevo: Zadrugar.

12. Поповић, Јово (1936), „Петар Кочић према селу и аграрном питању“, Преглед, Сарајево, св. 153, књ. ХІІ, год. Х.

13. Поповић, Ранко (2017), „Стогодишњи помен Петру Кочићу“, у: Читати и бити. Книжевне анализе, Бања Аука: Аруштво наставника српског језика и књижевности.

14. Радуловић, др Јован (2010), Славно доба Мостара (приредили Ранко Поповић и Арага Мастиловић), Мостар: СПЦО Мостар.

15. Секулић, Исидора (1959), „Петар Кочић“, у: Огледи, Нови СаА - БеограА: Матица српска - Српска књижевна задруга.

16. Ćorić, Boris (1966), „Pripovijetka 'Sudanija' u djelu Petra Kočića“, Putevi, Banja Luka, 5, XII.

17. Ћоровић, Вцадимир (1924), Босна и Хериеговина, Београд: СКЗ.

18. Чубриловић, Бранко (2016), Петар Кочић и његово доба, Бања Аука - БеограА: Задужбина „Петар Кочић“ (фототипско издање из 1934, Бања Аука - Загреб). 
Ranko V. Popović

\section{SERBIAN POLITICAL SATIRE IN BOSNIA AND HERZEGOVINA AT THE BEGINNING OF THE $20^{\mathrm{TH}}$ CENTURY}

\section{Summary}

The origins of the Serbian political satire, as regards the Bosnia and Herzegovina under the Austro-Hungarian occupation, can be traced back to the beginning of the $20^{\text {th }}$ century, immediately following the successful battle for establishing the religious and educational autonomy of the Serbian ethnic corpus within the country. At the same time, there emerges a new generation of young national tribunes, among whom there are some acknowledged writers of the time. In their view, satire is yet another form of political battle against the oppressor, with literary devices as means of opposition. With regard to its poetics, it is built upon the tradition of Domanović and Nušić, arguably two of the most prominent Serbian authors in this respect, but there are novelties with regard to the specific circumstances of the region. Although the sheer number of works is rather modest in terms of its quantity, its outreach in terms of literary history is undeniable, with champions of the genre in Bosnia and Herzegovina being Petar Kočić, Svetozar Ćorović, and Savo Skarić Zembilj. 